\title{
Evaluation of Validity and Standardization in the Wechsler Computer Memory Package in Iranian Students
}

\author{
Maryam Afsar ${ }^{1} *$
}

\section{ABSTRACT}

Introduction: Today evaluations of psychological indicators have a non new found role on the process of psychological evolution. One of these important indicators is memory. Purpose: the current research has the purpose of indicating the right norm from the Wechsler's school memory sub-test software on girl and boy students studying at pre-university level in the city of Tehran in the 87-88 school year. Procedure: this research by nature is a descriptive study and of a survey and normalization type which has applicative aspects. For this purpose a sample of 370 people ( $N=370)$ consisting of 170 men and 200 women from between students at the pre-university level of the province of Tehran were selected by using multistage cluster sampling. To evaluate constructive validity and factorial structure of this test, factorial test was used and to compare the averages of the two groups (girl and boy) an independence t test was used. Also to calculate the final test coefficient from the internal consistency method calculation of Cronbach's alpha coefficient has been used and from the retest method calculation of Pearson's correlation coefficient between the scores obtained from two times performing the test has been used. Findings: the results obtained from the research showed between all of the 8 dimensions of Wechsler's memory in the space of two performance in the frame of retest a positive meaningful relation exists $(\mathrm{p}<0 / 0001)$. Also the highest rate of correlation belonged to the reverse visual memory component $(\mathrm{r}=0 / 83)$ and the lowest index of correlation belonged to the auditory memory span component $(\mathrm{r}=0 / 40)$. Validation by using the retest method showed that between all the dimensions in the frame of two computer performance and a monthly retest a meaningful correlation exists among which the sum of the auditory memory ( $r=0 / 82$ ) had the highest correlation and the sum of the visual memory $(r=0 / 53)$ showed the lowest correlation. By using the independent $t$ test comparison of the average score of boys and girls in the multiple memory dimensions showed that between the two groups considering the dimensions no meaningful difference exists ( $p>0 / 05)$. Conclusion: the current research findings can be considered in the application areas and in the area of psychometrics it can open the path.

Keywords: Weschler memory, computer software, auditory memory, visual memory.

\footnotetext{
${ }^{1}$ MA, psychometric in central tehran of azad university, Tehran, Iran.

*Responding Author

(C) 2016 I M Afsar; licensee IJIP. This is an Open Access Research distributed under the terms of the Creative Commons Attribution License (http://creativecommons.org/licenses/by/2.0), which permits unrestricted use, distribution, and reproduction in any Medium, provided the original work is properly cited.
} 


\section{Evaluation of Validity and Standardization in the Wechsler Computer Memory Package in Iranian Students}

The term memory covers a general meaning and refers to that group of psychological processes which enables a person to store experiences and perceptions and remembering them again. Memory is one of the bases of learning, thinking, creativity, programming and our daily behavior. All of our social behavior needs memory such that a person without memory cannot interact with other people, perform family or ethnic traditions and customs and show their emotions (Ganji, 1997). For now evaluation of memory and determination of the type of dysfunction are among the most psychometric discussions and along the effort to understand the nature and processes of memory, effort in the innovation of tests of evaluation of memory have gained more speed (Faryar \& Rakhshan, 1997).

Today many tests are used around the world. One of the most comprehensive and complete tests available for evaluation of memory is Weschler's scale of memory. But because this scale like most psychological tests has a nature in relation with culture, using them in testing of other nations needs passing the process of normalization. This scale has become a software in Iran and has been calculated by balanced table of norms. Now the need for normalization of this scale in a frame of computer package is felt more than before such that if performed in our country we could evaluate the ability of memory and intelligence with respect to the people of this society's average response. Therefore we are trying to normalize this test in the Iranian community. By considering the latter the purpose of the current research is the evaluation of validity and normalization of Weschler's memory subtest on a sample of pre-university girl and boy students of the city of Tehran.

\section{METHODS}

The current research by nature is a descriptive research (no experimental) and is of survey and normalization type which has applicational aspects. The sampling process in this study consists of two separate samples: a sample to determine validity and reliability of the final test and a sample to evaluate the retest correlation coefficient. With respect to the nature of the study and the use of factorial analysis method, a volume of sampling of 300 people for pre-university girl students and 350 people for pre-university boy students was determined. The clustering sampling method was used. On this basis the 22 areas of the province of Tehran were divided to 5 areas of south, north, east, west and central. Then 300 of pre-university girl students and 350 people among pre-university boy students were selected using the multistage clustering sampling. Before analysis the gathered data were evaluated so in case of possible defect, the data that had defect were removed. After evaluation of the data 370 people's data were selected for analysis and the gathered data were analyzed. In the first stage a sample of 39 people were selected randomly and a 90 question questionnaire was performed in order to calculate content validity and to evaluate the questions in terms of writing and understanding. In order to provide scientific and logical backup using library study of theoretical foundations about intelligence and memory inside and outside the country were gathered. After library study by using field method, the existing questionnaires were gathered so that by detailed evaluation and study of them, the 


\section{Evaluation of Validity and Standardization in the Wechsler Computer Memory Package in Iranian Students}

position of the existing memory criteria were identified. In order to evaluate construct validity and factorial structure of this test, factorial test and to compare the averages of the two independent groups (boy and girl) the independent $t$ test was used. To calculate the final coefficient of the test the internal consistency, meaning that Cronbach's alpha coefficient calculation was used and by the retest method, meaning that Pearson's correlation coefficient calculation was used among the scores obtained from two times performance of the test.

\section{Tools}

1. Computer package of Weschler's memory scale: the Weschler's memory test presents wide information in 7 areas: 1-general knowledge and personal information, 2-awareness of time and place, 3-mind control, 4-numerical memory, 5-evoking words, 6-auditory memory, 7-visual memory. Each of the mentioned criteria contains subtests. Grading of each criteria is done separately and according to different criteria and finally the total scores determine the total memory share. Calculation of the memory share is done by conversion of the score of each group to the average of 100 and standard deviation of 15. The maximum score that a person can obtain in this test is 96 .

\section{Statistical analysis}

In the current study with respect to the nature of research and with the purpose of evaluation of construction validity and also factorial structure of Weschler's memory test software from the factorial test and for comparison of the averages of the testables with respect to the gender criteria independent $t$ test was used. Also to evaluate the final coefficient of the test internal consistency method, meaning calculation of Cronbach's alpha coefficient and the retest method with calculation of Pearson's correlation coefficient among the obtained scores from two times performing the test were used.

\section{RESULTS}

The findings from the analysis of data in two parts, descriptive (the demographic distribution) and inferential (independent t test, Pearson's correlation test and Cronbach's alpha coefficient calculation) using the statistical software of SPSS version 19 were analyzed which are shown in the tables below.

\section{Demographic features of participants}

Table 1: Distribution of the Frequency of Participants according to gender

\begin{tabular}{|c|c|c|}
\hline Gender & Frequency & Percent \\
\hline Boy & 190 & 51.4 \\
\hline Girl & 180 & 48.6 \\
\hline Sum & 370 & 100 \\
\hline
\end{tabular}

As you can see in the table 1, 51.4\% of the research participants consist of child boys. 
Evaluation of Validity and Standardization in the Wechsler Computer Memory Package in Iranian Students

Auditory memory scores towards forward

Table 2: index of central tendency criteria and distribution of the auditory memory scores towards forward

\begin{tabular}{|c|c|c|c|c|c|c|c|c|}
\hline & Mean & Median & Mode & Variance & $\begin{array}{c}\text { standard } \\
\text { deviation }\end{array}$ & $\begin{array}{c}\text { range } \\
\text { of } \\
\text { changes }\end{array}$ & minimum & maximum \\
\hline $\begin{array}{c}\text { Computer } \\
\text { performance }\end{array}$ & 6.69 & 6 & 6 & 4.82 & 2.19 & 13 & 1 & 14 \\
\hline $\begin{array}{c}\text { Computer } \\
\text { re- } \\
\text { performance }\end{array}$ & 6.62 & 7 & 7 & 6.35 & 2.52 & 13 & 1 & 14 \\
\hline $\begin{array}{c}\text { pen paper } \\
\text { performance }\end{array}$ & 6.61 & 6 & 6 & 6.67 & 2.16 & 12 & 1 & 13 \\
\hline
\end{tabular}

As shown in the table 2, auditory memory scores average towards forward in computer performance is 6/69, computer rerun is 6/62 and in pen paper performance is $6 / 61$ in which the computer performance scores average is more than the other two cases.

\section{Reverse auditory memory scores}

Table 3: index of central tendency criteria and distribution of the Reverse auditory memory scores

\begin{tabular}{|c|c|c|c|c|c|c|c|c|}
\hline & Mean & Median & Mode & Variance & $\begin{array}{c}\text { standard } \\
\text { deviation }\end{array}$ & $\begin{array}{c}\text { range } \\
\text { of } \\
\text { changes }\end{array}$ & minimum & maximum \\
\hline $\begin{array}{c}\text { Computer } \\
\text { performance }\end{array}$ & 6.83 & 7 & 7 & 7.50 & 2.74 & 14 & 0 & 14 \\
\hline $\begin{array}{c}\text { Computer } \\
\text { re- } \\
\text { performance }\end{array}$ & 6.88 & 6 & 7 & 8.37 & 2.89 & 13 & 1 & 14 \\
$\begin{array}{c}\text { pen paper } \\
\text { performance }\end{array}$ & 6.80 & 6 & 6 & 8.13 & 2.85 & 14 & 0 & 14 \\
\hline
\end{tabular}

As shown in the table 3, the reverse auditory memory scores average in the computer performance is $6 / 83$, in computer rerun is $6 / 88$ and in pen paper performance is $6 / 80$ in which the computer rerun scores average is more than the other two cases. Average scores of the three cases of performance in reverse auditory memory is more than the auditory memory scores average towards forward. 
Evaluation of Validity and Standardization in the Wechsler Computer Memory Package in Iranian Students

\section{Auditory memory total scores}

Table 4: index of central tendency criteria and distribution of the Auditory memory total scores

\begin{tabular}{|c|c|c|c|c|c|c|c|c|}
\hline & Mean & Median & Mode & Variance & $\begin{array}{c}\text { standard } \\
\text { deviation }\end{array}$ & $\begin{array}{c}\text { range } \\
\text { of } \\
\text { changes }\end{array}$ & minimum & maximum \\
\hline $\begin{array}{c}\text { Computer } \\
\text { performance }\end{array}$ & 13.52 & 13 & 11 & 4.26 & 18.17 & 25 & 2 & 27 \\
\hline $\begin{array}{c}\text { Computer } \\
\text { re- } \\
\text { performance }\end{array}$ & 13.51 & 13 & 12 & 4.49 & 20.24 & 22 & 3 & 25 \\
\hline $\begin{array}{c}\text { pen paper } \\
\text { performance }\end{array}$ & 13.29 & 12 & 12 & 4.42 & 19.58 & 24 & 3 & 27 \\
\hline
\end{tabular}

As can be seen in the table 4, auditory memory total scores average in the computer performance is $13 / 52$, in the computer rerun is $13 / 51$ and in the pen paper performance is $13 / 29$ in which the computer performance scores average is more than the other two cases.

\section{Visual memory scores towards forward}

Table 5: index of central tendency criteria and distribution of the Visual memory scores towards forward

\begin{tabular}{|c|c|c|c|c|c|c|c|c|}
\hline & Mean & Median & Mode & $\begin{array}{c}\text { standard } \\
\text { deviation }\end{array}$ & Variance & $\begin{array}{c}\text { range } \\
\text { of } \\
\text { changes }\end{array}$ & minimum & maximum \\
\hline $\begin{array}{c}\text { Computer } \\
\text { performance }\end{array}$ & 7.67 & 8 & 9 & 2.87 & 8.26 & 14 & 0 & 14 \\
\hline $\begin{array}{c}\text { Computer } \\
\text { re- } \\
\text { performance }\end{array}$ & 7.79 & 7 & 7 & 2.98 & 8.89 & 13 & 1 & 14 \\
\hline $\begin{array}{c}\text { pen paper } \\
\text { performance }\end{array}$ & 7.66 & 7 & 7 & 3.01 & 9.10 & 13 & 1 & 14 \\
\hline
\end{tabular}

As can be seen in the table 5, visual memory scores average towards forward in the computer performance is 7/67, in the computer rerun is 7/79 and in the pen paper performance is 7/66 in which the computer rerun scores average is more than the other two cases. 
Evaluation of Validity and Standardization in the Wechsler Computer Memory Package in Iranian Students

\section{Reverse visual memory scores}

Table 6: index of central tendency criteria and distribution of the Visual Reverse visual memory scores

\begin{tabular}{|c|c|c|c|c|c|c|c|c|}
\hline & Mean & Median & Mode & $\begin{array}{c}\text { standard } \\
\text { deviation }\end{array}$ & Variance & $\begin{array}{c}\text { range } \\
\text { of } \\
\text { changes }\end{array}$ & minimum & maximum \\
\hline $\begin{array}{c}\text { Computer } \\
\text { performance }\end{array}$ & 8.44 & 9 & 9 & 3.11 & 9.70 & 14 & 0 & 14 \\
\hline $\begin{array}{c}\text { Computer } \\
\text { re- } \\
\text { performance }\end{array}$ & 8.23 & 9 & 9 & 2.71 & 7.37 & 12 & 2 & 14 \\
\hline $\begin{array}{c}\text { pen paper } \\
\text { performance }\end{array}$ & 8.38 & 8 & 9 & 3.05 & 9.32 & 12 & 2 & 14 \\
\hline
\end{tabular}

As can be seen in the table 6, the reverse visual memory scores average in the computer performance is $8 / 44$, in the computer rerun $8 / 23$ and in the pen paper performance is $8 / 38$ in which the computer performance scores average is more than the other two cases. The reverse visual memory scores average is more than the visual memory scores average towards forward.

\section{Visual memory total scores}

Table 7: index of central tendency criteria and distribution of the Visual memory total scores

\begin{tabular}{|c|c|c|c|c|c|c|c|c|}
\hline & Mean & Median & Mode & $\begin{array}{c}\text { standard } \\
\text { deviation }\end{array}$ & Variance & $\begin{array}{c}\text { range } \\
\text { of } \\
\text { changes }\end{array}$ & minimum & maximum \\
\hline $\begin{array}{c}\text { Computer } \\
\text { performance }\end{array}$ & 16.12 & 16 & 16 & 3.76 & 14.19 & 20 & 5 & 25 \\
\hline $\begin{array}{c}\text { Computer } \\
\text { re- } \\
\text { performance }\end{array}$ & 16.02 & 16 & 15 & 3.63 & 13.23 & 22 & 3 & 25 \\
\hline $\begin{array}{c}\text { pen paper } \\
\text { performance }\end{array}$ & 16.04 & 16 & 15 & 3.81 & 14.52 & 19 & 7 & 26 \\
\hline
\end{tabular}

As can be seen in the table 7, visual memory total scores average in the computer performance is $16 / 12$, in the computer rerun is $16 / 02$ and in the pen paper is $16 / 04$ in which the computer performance scores average is more than the other two cases. The visual memory total scores average is more than the auditory memory total scores average. 
Evaluation of Validity and Standardization in the Wechsler Computer Memory Package in Iranian Students

\section{Auditory memory span scores}

Table 8: index of central tendency criteria and distribution of the Auditory memory span scores

\begin{tabular}{|c|c|c|c|c|c|c|c|c|}
\hline & Mean & Median & Mode & $\begin{array}{c}\text { standard } \\
\text { deviation }\end{array}$ & Variance & $\begin{array}{c}\text { range } \\
\text { of } \\
\text { changes }\end{array}$ & minimum & maximum \\
\hline $\begin{array}{c}\text { Computer } \\
\text { performance }\end{array}$ & 5.89 & 6 & 5 & 1.21 & 1.48 & 6 & 3 & 9 \\
\hline $\begin{array}{c}\text { Computer } \\
\text { re- } \\
\text { performance }\end{array}$ & 5.97 & 6 & 6 & 1.01 & 1.03 & 5 & 3 & 8 \\
\hline $\begin{array}{c}\text { pen paper } \\
\text { performance }\end{array}$ & 5.75 & 6 & 6 & 1.29 & 1.67 & 7 & 2 & 9 \\
\hline
\end{tabular}

As shown in the table 8 , the auditory memory span scores in the computer performance is $5 / 89$, in the computer rerun is 5/97 and in the pen paper performance is 5/75 in which the computer rerun scores is more than the other two cases.

\section{Visual memory span scores}

Table 9: index of central tendency criteria and distribution of the Visual memory span scores

\begin{tabular}{|c|c|c|c|c|c|c|c|c|}
\hline & Mean & Median & Mode & $\begin{array}{c}\text { standard } \\
\text { deviation }\end{array}$ & Variance & $\begin{array}{c}\text { range } \\
\text { of } \\
\text { changes }\end{array}$ & minimum & maximum \\
\hline $\begin{array}{c}\text { Computer } \\
\text { performance }\end{array}$ & 6.48 & 7 & 7 & 1.71 & 2.94 & 9 & 0 & 9 \\
\hline $\begin{array}{c}\text { Computer } \\
\text { re- } \\
\text { performance }\end{array}$ & 6.42 & 6 & 6 & 1.66 & 2.78 & 8 & 1 & 9 \\
\hline $\begin{array}{c}\text { pen paper } \\
\text { performance }\end{array}$ & 6.38 & 6 & 6 & 1.51 & 2.28 & 9 & 1 & 10 \\
\hline
\end{tabular}

As shown in the table 9, the visual memory span scores in the computer performance is $6 / 48$,in the computer rerun is $6 / 42$ and in the pen paper performance is $6 / 38$ in which the computer performance scores average is more than the other two cases. The visual memory span scores average is more than the auditory memory span scores average. 


\section{Evaluation of Validity and Standardization in the Wechsler Computer Memory Package in Iranian Students}

Pearson's correlation coefficients in the two computer and paper performance

Table 10: Pearson's correlation coefficients

\begin{tabular}{|c|c|c|c|c|}
\hline & Index & correlation & $\begin{array}{c}\text { Coefficient of } \\
\text { Determination }\end{array}$ & Sig. \\
\hline 1 & forward Auditory & 0.69 & 48 & 0.000 \\
\hline 2 & Reverse auditory & 0.78 & 61.7 & 0.000 \\
\hline 3 & $\begin{array}{c}\text { Auditory } \\
\text { memory total }\end{array}$ & 0.70 & 49.9 & 0.000 \\
\hline 4 & forward Visual & 0.75 & 56.5 & 0.000 \\
\hline 5 & Reverse visual & 0.83 & 70 & 0.000 \\
\hline 6 & $\begin{array}{c}\text { Visual memory } \\
\text { total }\end{array}$ & 0.73 & 53.5 & 0.000 \\
\hline 7 & $\begin{array}{c}\text { Auditory } \\
\text { memory span }\end{array}$ & 0.40 & 16.2 & 0.000 \\
\hline 8 & $\begin{array}{c}\text { Visual memory } \\
\text { span }\end{array}$ & 0.65 & 42.2 & 0.000 \\
\hline
\end{tabular}

As is seen in the following table 10, in the performance of the parallel method, in the total scores and subscales, the least correlation has been $0 / 40$ (auditory memory span) and the most correlation has been 0/30 (reverse visual memory), the other correlation coefficients also have been between $0 / 40$ and $0 / 83$. In the case of the degree of correlations also in the reverse visual memory, it is very high, in the auditory memory span, it is medium and in the other scores high correlation is seen. Also the amount of the level of meaning fullness calculated in the meaningful tests has a correlation coefficient of less than $0 / 01$ on the basis of which the coefficients calculated are meaningful. Therefore these scores obtained from the test of computer performance with the pen paper performance scores have had meaningful correlation in the level of medium, high and very high and this indicates the high validity of the computer software.

\section{The t test related to the evaluation of the meaningful relation}

In this section the meaningfulness of the difference between the two computer and pen paper performances has been evaluated. The table below shows the findings related to the correlated $t$ test. 
Evaluation of Validity and Standardization in the Wechsler Computer Memory Package in Iranian Students

Table 11: difference between the two computer and pen paper performances

\begin{tabular}{|c|c|c|c|c|c|c|c|}
\hline Index & $\begin{array}{c}\text { Computer } \\
\text { performance }\end{array}$ & Mean & $\begin{array}{l}\text { standard } \\
\text { deviation }\end{array}$ & $\begin{array}{c}\text { Means } \\
\text { difference }\end{array}$ & $T$ & df & Sig. \\
\hline \multirow[t]{2}{*}{$\begin{array}{l}\text { forward } \\
\text { Auditory }\end{array}$} & $\begin{array}{c}\text { Primary } \\
\text { performance }\end{array}$ & 6.69 & 2.19 & 0.08 & 0.88 & 369 & 0.37 \\
\hline & $\begin{array}{c}\text { secondary } \\
\text { performance }\end{array}$ & 6.61 & 2.16 & & & & \\
\hline \multirow[t]{2}{*}{$\begin{array}{l}\text { Reverse } \\
\text { auditory }\end{array}$} & $\begin{array}{c}\text { Primary } \\
\text { performance }\end{array}$ & 6.83 & 2.74 & 0.03 & 0.31 & 369 & 0.75 \\
\hline & $\begin{array}{c}\text { secondary } \\
\text { performance }\end{array}$ & 6.80 & 2.85 & & & & \\
\hline \multirow{2}{*}{$\begin{array}{c}\text { Auditory } \\
\text { memory } \\
\text { total }\end{array}$} & $\begin{array}{c}\text { Primary } \\
\text { performance }\end{array}$ & 13.52 & 4.26 & 0.23 & 1.34 & 369 & 0.18 \\
\hline & $\begin{array}{c}\text { secondary } \\
\text { performance }\end{array}$ & 13.29 & 4.42 & & & & \\
\hline \multirow[t]{2}{*}{$\begin{array}{c}\text { forward } \\
\text { Visual }\end{array}$} & $\begin{array}{c}\text { Primary } \\
\text { performance }\end{array}$ & 7.67 & 2.87 & 0.01 & 0.10 & 369 & 0.92 \\
\hline & $\begin{array}{c}\text { secondary } \\
\text { performance }\end{array}$ & 7.66 & 3.01 & & & & \\
\hline \multirow[t]{2}{*}{$\begin{array}{c}\text { Reverse } \\
\text { visual }\end{array}$} & $\begin{array}{c}\text { Primary } \\
\text { performance }\end{array}$ & 8.44 & 3.11 & 0.06 & 0.67 & 369 & 0.49 \\
\hline & $\begin{array}{c}\text { secondary } \\
\text { performance }\end{array}$ & 8.38 & 3.05 & & & & \\
\hline \multirow{2}{*}{$\begin{array}{c}\text { Visual } \\
\text { memory } \\
\text { total }\end{array}$} & $\begin{array}{c}\text { Primary } \\
\text { performance }\end{array}$ & 16.12 & 3.76 & 0.07 & 0.50 & 369 & 0.61 \\
\hline & $\begin{array}{c}\text { secondary } \\
\text { performance }\end{array}$ & 16.04 & 3.81 & & & & \\
\hline \multirow{2}{*}{$\begin{array}{c}\text { Auditory } \\
\text { memory } \\
\text { span }\end{array}$} & $\begin{array}{c}\text { Primary } \\
\text { performance }\end{array}$ & 5.89 & 1.21 & 0.13 & 1.85 & 369 & 0.06 \\
\hline & $\begin{array}{c}\text { secondary } \\
\text { performance }\end{array}$ & 5.75 & 1.29 & & & & \\
\hline \multirow[t]{2}{*}{$\begin{array}{c}\text { Visual } \\
\text { memory } \\
\text { span }\end{array}$} & $\begin{array}{c}\text { Primary } \\
\text { performance }\end{array}$ & 6.48 & 1.71 & 0.10 & 1.41 & 369 & 0.15 \\
\hline & $\begin{array}{c}\text { secondary } \\
\text { performance }\end{array}$ & 6.38 & 1.51 & & & & \\
\hline
\end{tabular}




\section{Evaluation of Validity and Standardization in the Wechsler Computer Memory Package in Iranian Students}

The results of the table 11 show that in neither of the indices meaningful difference between the computer performance scores and pen paper performance has not been seen.

\section{Finding validity by using the retest method}

After the computer performance of the test, the testable with a span of one month from the computer test, were re-evaluated. The table below shows the level of correlation between the retesting.

Table 12: level of correlation between the re-testing

\begin{tabular}{|c|c|c|c|c|}
\hline & Index & correlation & $\begin{array}{c}\text { Coefficient of } \\
\text { Determination }\end{array}$ & Sig. \\
\hline 1 & forward Auditory & 0.69 & 48 & 0.000 \\
\hline 2 & Reverse auditory & 0.78 & 61.7 & 0.000 \\
\hline 3 & $\begin{array}{c}\text { Auditory } \\
\text { memory total }\end{array}$ & 0.70 & 49.9 & 0.000 \\
\hline 4 & forward Visual & 0.75 & 56.5 & 0.000 \\
\hline 5 & Reverse visual & 0.83 & 70 & 0.000 \\
\hline 6 & $\begin{array}{c}\text { Visual memory } \\
\text { total }\end{array}$ & 0.73 & 53.5 & 0.000 \\
\hline 7 & $\begin{array}{c}\text { Auditory } \\
\text { memory span }\end{array}$ & 0.40 & 16.2 & 0.000 \\
\hline 8 & $\begin{array}{c}\text { Visual memory } \\
\text { span }\end{array}$ & 0.65 & 42.2 & 0.000 \\
\hline
\end{tabular}

As is seen in the table 12 in the rerun, the reverse visual memory had the least correlation (0/61) and auditory memory had the most correlation of $0 / 80$ and the other correlation coefficients are also between $0 / 61$ to $0 / 82$. In the case of the degree of correlations also, the auditory memory total scales and the auditory memory toward forward have very high correlation and in the other scales are at a high level. Also the amount of the level of meaningfulness calculated in the meaningful tests the correlation coefficient has been less than $0 / 01$ which on this basis the coefficients calculated is meaningful. Therefore the scores obtained from two times performance of the computer test in a span of 1 month, show a meaningful correlation at a very high level and high which this has been indicative of the high validity of the computer software.

\section{The t test in the computer rerun}

The difference between computer rerun scores was evaluated by the related test which is shown in the table below. 
Evaluation of Validity and Standardization in the Wechsler Computer Memory Package in Iranian Students

Table 13: The $t$ test in the computer rerun

\begin{tabular}{|c|c|c|c|c|c|c|c|}
\hline Index & $\begin{array}{c}\text { Computer } \\
\text { performance }\end{array}$ & Mean & $\begin{array}{l}\text { standard } \\
\text { deviation }\end{array}$ & $\begin{array}{c}\text { Means } \\
\text { difference }\end{array}$ & $T$ & df & Sig. \\
\hline \multirow[t]{2}{*}{$\begin{array}{l}\text { forward } \\
\text { Auditory }\end{array}$} & $\begin{array}{c}\text { Primary } \\
\text { performance }\end{array}$ & 6.69 & 2.19 & 0.07 & 0.95 & 369 & 0.34 \\
\hline & $\begin{array}{c}\text { secondary } \\
\text { performance }\end{array}$ & 6.62 & 2.52 & & & & \\
\hline \multirow[t]{2}{*}{$\begin{array}{l}\text { Reverse } \\
\text { auditory }\end{array}$} & $\begin{array}{c}\text { Primary } \\
\text { performance }\end{array}$ & 6.83 & 2.74 & -0.05 & -0.44 & 369 & 0.65 \\
\hline & $\begin{array}{c}\text { secondary } \\
\text { performance }\end{array}$ & 6.88 & 2.89 & & & & \\
\hline \multirow{2}{*}{$\begin{array}{l}\text { Auditory } \\
\text { memory } \\
\text { total }\end{array}$} & $\begin{array}{c}\text { Primary } \\
\text { performance }\end{array}$ & 13.52 & 4.26 & 0.02 & 0.12 & 369 & 0.90 \\
\hline & $\begin{array}{c}\text { secondary } \\
\text { performance }\end{array}$ & 13.51 & 4.49 & & & & \\
\hline \multirow[t]{2}{*}{$\begin{array}{l}\text { forward } \\
\text { Visual }\end{array}$} & $\begin{array}{c}\text { Primary } \\
\text { performance }\end{array}$ & 7.67 & 2.87 & -0.12 & -0.96 & 369 & 0.33 \\
\hline & $\begin{array}{c}\text { secondary } \\
\text { performance }\end{array}$ & 7.79 & 2.98 & & & & \\
\hline \multirow[t]{2}{*}{$\begin{array}{c}\text { Reverse } \\
\text { visual }\end{array}$} & $\begin{array}{c}\text { Primary } \\
\text { performance }\end{array}$ & 8.44 & 3.11 & 0.21 & 1.58 & 369 & 0.11 \\
\hline & $\begin{array}{c}\text { secondary } \\
\text { performance }\end{array}$ & 8.23 & 2.71 & & & & \\
\hline \multirow{2}{*}{$\begin{array}{c}\text { Visual } \\
\text { memory } \\
\text { total }\end{array}$} & $\begin{array}{c}\text { Primary } \\
\text { performance }\end{array}$ & 16.12 & 3.76 & 0.10 & 0.52 & 369 & 0.60 \\
\hline & $\begin{array}{c}\text { secondary } \\
\text { performance }\end{array}$ & 16.02 & 3.63 & & & & \\
\hline \multirow{2}{*}{$\begin{array}{c}\text { Auditory } \\
\text { memory } \\
\text { span }\end{array}$} & $\begin{array}{c}\text { Primary } \\
\text { performance }\end{array}$ & 5.89 & 1.21 & -0.08 & -1.65 & 369 & 0.09 \\
\hline & $\begin{array}{c}\text { secondary } \\
\text { performance }\end{array}$ & 5.97 & 1.01 & & & & \\
\hline \multirow[t]{2}{*}{$\begin{array}{c}\text { Visual } \\
\text { memory } \\
\text { span }\end{array}$} & $\begin{array}{c}\text { Primary } \\
\text { performance }\end{array}$ & 6.48 & 1.71 & 0.06 & 0.77 & 369 & 0.43 \\
\hline & $\begin{array}{c}\text { secondary } \\
\text { performance }\end{array}$ & 6.42 & 1.66 & & & & \\
\hline
\end{tabular}




\section{Evaluation of Validity and Standardization in the Wechsler Computer Memory Package in Iranian Students}

The table 13 results show that in neither of the indices, there are no meaningful difference between the computer rerun scores.

\section{Standard table (norm)}

Before calculations related to the norm in order to specify the need for independent norm tables to differentiate gender, eight fold scores obtained in the group of girls and boys was compared. The table below shows the comparison of the average scores of girls and boys in the first computer performance.

Table 14: comparison of the average scores of girls and boys in the first computer performance

\begin{tabular}{|c|c|c|c|c|c|c|c|}
\hline Index & Groups & Mean & $\begin{array}{l}\text { standard } \\
\text { deviation }\end{array}$ & $\begin{array}{c}\text { Means } \\
\text { difference }\end{array}$ & $T$ & df & Sig. \\
\hline \multirow[t]{2}{*}{$\begin{array}{c}\text { forward } \\
\text { Auditory }\end{array}$} & boy & 6.54 & 2.15 & 0.07 & -1.37 & 369 & 0.17 \\
\hline & girl & 6.85 & 2.23 & & & & \\
\hline \multirow[t]{2}{*}{$\begin{array}{l}\text { Reverse } \\
\text { auditory }\end{array}$} & boy & 6.65 & 2.49 & -0.05 & \begin{tabular}{|l|}
-1.33 \\
\end{tabular} & 369 & 0.18 \\
\hline & girl & 7.03 & 2.97 & & & & \\
\hline \multirow[t]{2}{*}{$\begin{array}{c}\text { Auditory } \\
\text { memory } \\
\text { total }\end{array}$} & boy & 13.18 & 4.92 & 0.02 & $\begin{array}{l}-1.56 \\
\end{array}$ & 369 & 0.11 \\
\hline & girl & 13.88 & 4.57 & & & & \\
\hline \multirow[t]{2}{*}{$\begin{array}{c}\text { forward } \\
\text { Visual } \\
\end{array}$} & boy & 7.73 & 3.03 & -0.12 & 0.40 & 369 & 0.68 \\
\hline & girl & 7.61 & 2.70 & & & & \\
\hline \multirow[t]{2}{*}{$\begin{array}{c}\text { Reverse } \\
\text { visual }\end{array}$} & boy & 8.53 & 2.96 & 0.21 & 0.56 & 369 & 0.57 \\
\hline & girl & 8.35 & 3.27 & & & & \\
\hline \multirow[t]{2}{*}{$\begin{array}{c}\text { Visual } \\
\text { memory } \\
\text { total }\end{array}$} & boy & 16.26 & 3.64 & 0.10 & 0.77 & 369 & 0.44 \\
\hline & girl & 15.96 & 3.89 & & & & \\
\hline \multirow[t]{2}{*}{$\begin{array}{c}\text { Auditory } \\
\text { memory } \\
\text { span }\end{array}$} & boy & 5.84 & 1.20 & -0.08 & -0.80 & 369 & 0.42 \\
\hline & girl & 5.94 & & & & & \\
\hline \multirow[t]{2}{*}{$\begin{array}{c}\text { Visual } \\
\text { memory } \\
\text { span }\end{array}$} & boy & 6.45 & 1.22 & 0.06 & $\begin{array}{l}-0.41 \\
\end{array}$ & 369 & 0.67 \\
\hline & girl & 6.52 & 1.70 & & & & \\
\hline
\end{tabular}




\section{Evaluation of Validity and Standardization in the Wechsler Computer Memory Package in Iranian Students}

The findings in table 14 show that in all cases, meaningful difference between the scores of girls and boys in the first computer performance has not been seen therefore calculation of a separate norm is not needed.

\section{DISCUSSION}

The study considered, was a research in direction of evaluation of psychometric characters and normalization of Weschler's memory test software form in Iranian students. The results from the research showed that among all the eight fold dimensions of Weschler's test in terms of validity of retrieval, there is a positive meaningful relation. About the correlation coefficients obtained we can acknowledge that between all the dimensions in the frame of two computer performances and the rerun in one month a meaningful correlation existed, also the highest level of correlation belonged to the auditory memory and the lowest level of correlation belonged to the visual memory index.

On the other hand between the results obtained from the two groups of boys and girls meaningful differences were not seen. With regards to the survey from professors and specialists related to content validity and reliability calculated for the scale, we can say that the computer package is a credible software to measure students' memory. The results of this study is in line with some of the researches. Therefore people in some of these dimensions have more efficient memory and in some dimensions have weaker performance which is in accordance with Richard and vilkuiz (1990). They performed and showed three factors of memory dimension among children such that people are stronger in one dimension of memory than in the other dimensions which shows that people are not the same in different dimensions (auditory memory towards forward, reverse auditory memory, visual memory towards forward, reverse visual memory, auditory memory span and visual memory span).

This research is also in line with researches done by Shahim (1992) which performed the correlation between the revised form of Weschler's intelligence scale for children and Weschler's intelligence scale for preschool and kinder garden children for Iranian children. The results of this research showed that between girls and boys in neither dimensions of memory in a meaningful level no meaningful differences existed which shows that existence of memory is not influenced by demographic characteristics including gender. In a general view we can deduce that the computer software is a suitable tool for evaluation of students' memory and compared to pen paper tests it has more ability in interpretation of their intelligence and memory and has considerable validity and reliability and we can use this software in place of pen paper tests.

\section{RESEARCH LIMITATIONS}

This study in the process of performance has had limitations, some of these limitations consisted of: limited sample case under research was one of the obstacles, therefore extension of the results 


\section{Evaluation of Validity and Standardization in the Wechsler Computer Memory Package in Iranian Students}

should be done carefully. In addition lack of sufficient past research was other research limitations.

\section{SUGGESTIONS}

For the reason of importance of valid standard tools, it is suggested that this questionnaire be normalized at different cultural-social conditions and more widespread level. It is necessary that the current scale with the assistance of other researches and in different societies be repeated with the purpose of validity and normalization.

\section{Acknowledgments}

The author appreciates all those who participated in the study and helped to facilitate the research process.

\section{Conflict of Interests}

The author declared no conflict of interests.

\section{REFERENCES}

Akrami, Zahra. (1386). "Construct and normalization test motivation for advancing in high school students of area 7 of education and training of the city of Tehran", thesis of masters level of Allama Tabatabai University.

Anastazi. (1361). "Mental testing", translated by Mohammad naghi Barahany, Tehran: Tehran University publications.

Asmal, Gary. (1386). "Support your memory", translated by Hamid Mirza aghaii, Tehran new thinking site.

Atkinson, Rital and others. (1387). "Field of psychology", translated by Mohammad naghi Barahany and others, Tehran: Roshd publications.

Azkhosh, Manouchehr. (1382). "Psychological tests application", Tehran: Ravan publication.

Fariar, Akbar; Rakhshan, Fereidoon. (1382). Learning disabilities. Tabriz: Rah-e Roshan publications.

Ganji, Hamzeh. (1387). "Psychological tests", Tehran: Savalan publication.

Omidvar, Ahmad. (1384). "Special deficiencies in learning", Tehran: Sokhan Goftan publications. 